\title{
REFORMULASI BENTUK PERTANGGUNGJAWABAN PRESIDEN DALAM SISTEM PEMERINTAHAN PRESIDENSIAL
}

\author{
Sri Bintang Gelang \\ Program Magister Ilmu Hukum \\ Pascasarjana Universitas Islam Malang \\ Email : bintangriung@gmail.com
}

\begin{abstract}
Abstrak
DPR, MPR, dan Mahkamah Konstitusi sebagai pelaksana dari pada proses impeachment terhadap Presiden. Dengan proses politik berada DPR dan MPR (DPR proses awal yang memberikan usulan dan MPR proses akhir yang memutuskan Presiden dapat di imoeacment atau tidak) dan proses hukum berada di Mahkamah Konstitusi (proses pembuktian benar atau tidak telah di lakukan pelanggaran hukum sebagaimana ketentuan pasal 7A UUD NRI 1945). Sistem pertanggungjawaban Presiden setelah amandemen UUD 1945 merupakan sistem pertanggungjawaban hukum dalam sistem ketatanegaraan yakni pertanggungjawaban dengan materi pelanggaran hukum berupa perbuatan hukum pidana dan tindakan politik yang dilakukan dalam masa jabatan. Oleh karena itu, bentuk-bentuk pertanggungjawaban Presiden merupakan pertanggung-jawaban atas perbuatan hukum pidana dan/atau pertanggungjawaban politik karena ketidakmampuan memenuhi kewajiban sebagai Presiden Republik Indonesia yang kemudian dikualifisir sebagai pertanggungjawaban hukum dalam sistem ketatanegaraan dengan sanksi tertinggi, pemberhentian dari jabatan. Berangkat dari cara berpikir di atas, maka bentuk pertanggungjawaban Presiden menurut UUD 1945 khususnya Pasal 7A adalah bentuk pertanggungjawaban hukum yang terdiri dari pertanggungjawaban hukum pidana berupa pengkhianatan terhadap negara, korupsi, penyuapan, tindak pidana berat lainnya atau perbuatan tercela dan pertanggungjawaban hukum kebijakan Pemerintahan (policy) yakni terbukti tidak lagi memenuhi syarat sebagai Presiden berupa gagal mengemban amanah rakyat dan tidak dapat memenuhi kewajibannya sebagai Presiden, melanggar UUD dan tidak melaksanakan UU dan peraturan lainnya dengan sebaik-baiknya dan seadiladilnya, serta tidak berbakti kepada nusa dan bangsa.
\end{abstract}

Kata kunci: Reformulasi, Pertanggunngjawaban Presiden, Sistem Presidensial

\begin{abstract}
The DPR, MPR and the Constitutional Court act as implementers of the impeachment process against the President. With the political process in the DPR and the MPR (the initial process of the DPR which provides proposals and the $M P R$, the final process which decides whether the President can be imitated or not) and the legal process is in the Constitutional Court (the process of proving whether or not there has been a violation of the law as stipulated in article 7A of the Constitution NRI 1945). The President's accountability system after the amendment of the 1945 Constitution is a system of legal accountability in the
\end{abstract}


constitutional system, namely accountability with material violations of the law in the form of criminal acts and political acts committed during the term of office. Therefore, the forms of responsibility of the President are accountability for criminal acts and / or political responsibility due to the inability to fulfill his obligations as President of the Republic of Indonesia, which is later qualified as legal responsibility in the state administration system with the highest sanctions, dismissal from office. Departing from the way of thinking above, the form of responsibility for the President according to the 1945 Constitution, especially Article $7 A$ is a form of legal responsibility consisting of criminal liability in the form of treason against the state, corruption, bribery, other serious crimes or disgraceful acts and legal accountability for Government policies (policy) that is proven that they no longer fulfill the requirements as President in the form of failing to carry out the mandate of the people and failing to fulfill their obligations as President, violating the Constitution and not implementing laws and other regulations as well as possible and fairly, and not serving the country and the nation.

Keywords: Reformulation, President's Responsibility, Presidential System

\section{PENDAHULUAN}

Gagasan negara hukum demokratis memiliki akar sejarah yang cukup panjang, terutama dalam liku perkembangan konstitusi dan format ketatanegaraan termasuk didalamnya tentang kekuasaan Presiden. Sejalan dengan kesepakatan untuk mempertegas sistem pemerintahan Presidensil maka Presiden harus memiliki Legitimasi yang kuat. Legitimasi yang kuat itu hanya akan dapat di peroleh bila Presiden di pilih langsung oleh rakyat. Implikasi dan konsekwensi hukum dari pengisian jabatan Presiden melalui pemilihan langsung terhadap UUD 1945 adalah pertanggungjawaban Presiden harus di berikan kepada rakyat tidak lagi kepada MPR. Karena tidak adalagi hubungan pertanggungjawaban antara Presiden dengan MPR, maka sebagai penggantinya di perlukan adanya peranata impeachment dalam hubungannya dengan konsep tindakan terhadap pelanggaran oleh Presiden. ${ }^{1}$

Kekuasaaan dan sistem pertanggungjawaban Presiden tidak dapat di pisahkan dengan sistem pemerintahan yang dianut dalam suatu negara. Dalam kepustakaan dikenal dengan adanya tiga sistem kekuasaan, yaitu: ${ }^{2}$

1. Sistem Pemerintahan Parlementer

2. Sistem Pemerintahan Presidensial

3. Sistem Pemerintahan yang mengandung unsur-unsur, baik yang terdapat dalam sistem pemerintahan parlementer maupun yang terdapat dalam sistem pemerintahan presidensial. Terhadap sistem ketiga ini ada yang menamakannya semipresidential government

Dalam sistem pemerintahan Presidensial, lembaga kepresidenan mempunyai kedudukan yang penting. Hal ini disebabkan dalam sistem ini Presiden yang bertindak sebagai pelaksana eksekutif dan pemimpin kabinet akan

1 Jimly Asshiddiqie, Et Al, Gagasan Amandemen UUD 1945 Dan Pemilihan Presiden Secara Langsung (Jakarta : Sekretaris Jendral Dan Kepaniteraan Mahkamah Konstitusi RI, 2006) Hlm. 47-48

${ }^{2}$ Sri Soemantri, Hukum Tata Negara Indonesia Pemikiran Dan Pandangan, Pt Remaja Rosdakarya, Bandung 2014, Hlm 61 
banyak menentukan dalam jalannya roda pemerintahan. Unutk Indonesia kalau di perhatikan UUD 1945 bayak sekali pasal yang mengatur tentang lembaga kepresidenan bila di bandingkan dengan lembaga-lembaga negara lainnya, bahkan dengan MPR sekalipn. Dengan demikian, dapat dinyatakan bahwa UUD 1945 telah memberikan kedudukan yang kuat kepada lembaga kepresidenan. ${ }^{3}$

Presiden tidak bertanggungjawab kepada MPR kecuali jika ada tuntutan dari DPR kepada mahkamah konstitusi (MK) tentag adanya pelanggaran hukum dan konstitusi yang di lakukan oleh presiden. Apabila tuntutan tersebut di kuatkan oleh MK dalam satu keputusan, maka DPR dapat melanjutkan tuntutan pemberhentian Presiden kepada MPR.

Pengaturan hukum berkenaan dengan Pertanggungjawaban Presiden pasca reformasi belum diatur secara eksplisit, berbeda dengan sebelumnya reformasi Presiden bertanggungjawab kepada Majelis Permusyawaratan Rakyat (MPR). dalam UUD NRI 1945 pasca amandemen hanya mengatur berkenaan dengan pemberhentian Presiden dan wakil Presiden dalam masa jabatannya. Pasal 7A UUD'45 berbunyi “

Presiden dan/atau Wakil Presiden dapat diberhentikan dalam masa jabatannya oleh Majelis Permusyawaratan Rakyat atas usul Dewan Perwakilan Rakyat, baik apabila telah terbukti melakukan pelanggaran hukum berupa penghianatan terhadap negara, korupsi, penyuapan, tindak pidana berat lainnya, atau perbuatan tercela maupun apabila terbukti tidak lagi memenuhi syarat sebagai Presiden dan/atau Wakil Presiden.

Rumusan pasal tersebut hanya mengatur berkanaan dengan pelanggaran ataupun kejahatan yang terkait yang dilakukan oleh presiden dan/atau wakil presiden dalam masa jabatannya dan dapat diberhntikan dalam masa jabatannya dengan mekanisme Konstitusional oleh tiga lembaga negara yaitu DPR, MPR, MK. Tidak mengatur berkenaan dengan pertanggungjawaban Presiden dan atau Wakil Presiden dalam upaya melaporkan semua tindakan atau perbuatan hukum pemerintah baik yang di berikan oleh peraturan Perundang-Undangan ataupun yang berkenaan dengan perbuatan hukum yang belum diatur oleh peraturan Perundang-Undangan (diskresi/freis emmerson), dalam masa jabatannya. Maka dari itu, didalam penelitian ini penulis ingin menguraikan konsep peranggungjawaban Presiden selain pertanggungjawaban Presiden yang menuju kepada pranata Impeachment dengan ketentuan pelanggaran ataupun kejahatan seperti yang telah teratur didalam konstitusi. sementara ketentuan tersebut juga perlu meminta pertanggungjawaban dari sorang Presiden terhadap kebijakan yang dilakukan didalam menjalankan roda pemerintahan negara. Maka dari itu didalam penelitian ini, penulis ingin sedikit menguraikan bentuk pengaturan sistem pertanggungjawaban Presiden dan prosedur pertanggungjawaban Presiden dalam menjalankan pemerintahan negara, yang tidak selalu menuju pranata impeachment.

Secara teoritis, diharapkan dapat memberi sumbangan ilmiah bagi ilmu pengetahuan hukum dalam perkembangan hukum tatanegara. Dikhususnya dalam pemahaman teori tentang problematika pertanggungjawaban Presiden di Indonesia. Secara praktis, penelitian yang berfokus pada reformulasi pertanggungjawaban Presiden diharapkan bisa menjadi pertimbangan dan

${ }^{3}$ Bagir Manan, lembaga kepresidenan, Pusat Studi Hukum (PSH) Universitas Islam Indonesia dengan Gama Media, Yogyakarta, 1999. Hlm 31. 
sumbangan fikiran, serta dapat memberikan solusi dan kontribusi bagi pemangku kekuasaan legislatif dan eksekuif agar tidak melanggar hak-hak konstitusional berbangsa dan bernegara. Diharapkan dapat menghasilkan suatu kebijakan dalam reformulasi pertanggungjawaban Presiden selain Impeachment demi pembaharuan hukum di Indonesia.

\section{METODE PENELITIAN}

Jenis penelitian yang digunakan dalam penelitian ini adalah yuridis normatif. Adapaun pendekatan yang di gunakan dalam penelitian ini ada dua, yaitu : pendekatan konsep hukum (conceptual approach), pendekatan perundangundangan (statute approach). Didalam menganalisis, menggunakan metode deskriptif analisis ataupun content analysis yang menunjukan pada metode analisis yang integratif dan secara konseptual cendrung diarahkan untuk menemukan, mengidentifikasi, mengolah dan menganalisis bahan hukum untuk memahami makna, signifikansi dan relefansinya. Yang terdiri dari bahan hukum primer, bahan hukum sekunder, bahan hukum tersier. Semua data ini kami pilah yang relevan dan yang tidak relevan dalam penelitian.

\section{PEMBAHASAN}

Salah satu subsistem dari sistem pemerintahan Indonesia adalah prinsip negara hukum dan sistem konstitusional. ${ }^{4}$ yamin menjelaskan pengertian negara hukum dalam penjelasan UUD 1945 yaitu dalam negara dan masyarakat Indonesia, yang berkuasa bukannya manusia lagi seperti berlaku dalam negaranegara Indonesia lama aau dalam negara asing yang menjalankan kekuasaan penjajahan sebelum proklamas, melainkan warga Indonesia dalam suasana kemerdekaan yang di kuasai semata-mata oleh peraturan negara berupa perundang-undangan yang di buatnya sendiri. ${ }^{5}$

Lebih lanjut Yamin menyatakan bahwa dasar negara hukum tidak sama dengan negara hukum-adat atau hukum-agama, dan sangat berlainan dengan negara kekuasaan, karena dalam negara Republik Indonesia, peraturan negara tertulislah yang memerintah. Syarat negara hukum itu terdapat dalam kalimat pembukaan UUD 1945 yang berbunyi : "maka disusunlah kemerdekaan kebangsaan Indonesia itu dalam suatu Undang-Undang Dasar Negara Indonesia". ${ }^{6}$ pandangan ini menunjukan pandangan sempit mengenai negara hukum, yaitu hanya dalam arti due process of law, yang berarti segala tindakan dan kebijakan pemerintah dilakukan berdasarkan atas aturan hukum yang berlaku.

MPR memiliki kewenangan yang harus di putuskan dalam join session. Forum ini merupakan rapat gabungan antara DPR dan DPD. Kewenangan pertama, menetapkan perubahan UUD, kedua, mengangkat dan memberhantikan Presiden dan/atau Wakil Presiden. Khusus mengenai prosedur pemberhentian terdapat 3 point pertama, alasan pemberhentian, kedua, proses pengambilan keputusan; ketiga persidangan. Tim merumuskan alasan pemberhentian kedalam dua alasan yang di letakan dalam kerangka (i) kecendrungan dianut sistem

${ }^{4}$ Lihat Yusril Ihza Mahendra, Dinamika Tata Negara Indonesia, Gema Insani Press, Jakarta 1996. Hlm 39-61

5 Muhammad Yamin, Pembahasan Undang-Undang Dasar 1945, jilid keempat, Penerbit Yayasan Prapanca, 1960. Hlm 253.

${ }^{6}$ Ibid 
presidensil murni. (ii) pemilihan presiden secara langsung. Pemberhentian Presiden pada masa yang akan datang di harapkan tidak lagi menggunakan alasan politik, melainkan cukup dengan alasan hukum yakni pertama, pelanggaran hukum; kedua tidak mampu atau berhalangan tetap. Alasan-alasan ini paralel dengan sistem pemerintahan Presidensil. ${ }^{7}$ Dalam statemantnya Jimly menegaskan bila mau konsisten dengan sistem pemerintahan presidensil, yang masa jabatannya fixed term maka tidak ada lagi pertimbangan politik. Namun pelanggaran hukum tersebut tidak boleh di rumuskan seperti Amerika Serikat. ${ }^{8}$ DPR menjadi organ penuntut, sedangkan MPR menjadi organ pemutus.

Presiden merupakan pemegang kekuasaan eksekutif pada sistem pemerintahan presidensial. Dan mekanisme kontrol dilakukan lembaga perwakilan rakyat. ${ }^{9}$ Pasaca perubahan UUD 1945, secara garis besar ada tiga hal pokok menyangkut hubungan kekuasaan antara Presiden dan DPR. Pertama, hubungan legislasi (pembentukan Undang-undang). Kedua, hubungan dalam menetapkan anggaran dan belanja negara (APBN) dan ketiga, hubungan pengawasan. Selebihnya hubungan kekuasaan yang sifatnya insidental.

Dari tiga hubungan tersebut diatas antar Presiden dan DPR, penulis berpendapat bahwa hubungan kekuasan antara Presiden dan DPR pasca amandemen UUD 1945 tidak menggambarkan prinsip cheks and balances. Dari ketiga hubungan tersebut, secara politik dan hukum kedudukan DPR lebih kuat dibandingkan dengan DPR. Sebab Presiden akan kesulitan dalam menjalankan pemerintahan tanpa adanya dukungan dari DPR.

\section{Tinjauan lembaga negara yang berwenang menerima pertanggungjawaban Presiden}

Dalam literatur ilmu negara (Algemene Staatsleer, Theory Of State), dan dalam ilmu hukum tata negara (Staatsrecht Wetenschap, Constitusional Law), sistem pemerintahan diartikan sebagai tatanan hubungan pertanggungjawaban atas penyelenggaraan pemerintahan antara eksekutif, dan legislatif (parlemen). Dalam tatanan demokrasi di bedakan antara ${ }^{10}$ :

a. Sistem (pemerintahan) parlementer dengan ciri utama, kekuasaan eksekutif ditunjuk oleh kepala negara dengan dukungan kepercayaan dan bertanggungjawab kepada parlemen. Bertanggung jawab artinya, semua rencana program, dan kebijakan pemerintah (kabinet, dewan menteri) harus memperoleh dukungan anggota atau partai atau partai-partai mayoritas di parlemen. Dalam praktek ketatanegaraan, setiap kabinet yang baru akan menyampaikan kepada parlemen dasar-dasar kebijakan dan program yang

${ }^{7}$ Margarito Kamis, Pembatasan Kekuasaan Presiden, Pergeseran Kekuasaan Presiden Pasca Amandemen UUD 1945, SETARA PRESS, (Malang 2014), Hal 40

${ }^{8}$ Jimly Assiddiqie juga menyenut Prancis yang menurutnya terdapat dua alasan, demikian juga Taiwan, Jepang dan Philiphine. Tetapi tidak semua negara mengaitkan pelanggaran hukum tersebut dengan tindak pidana. Soal ini seringkali disalah mengerti oleh kebanyakan orang seolaholah pelanggaran hukum selalu tindak pidana. Jerman misalnya hanya menyebutkan pelanggaran hukum dan Konstitusi. Lihat : Jimly Asshiddiqie Dalam MPR, Buku Kedua Jilid 3A... Op.Cit., 7677. Lihat: juga Jimly Asshiddiqie Dalam MPR, Buku Kedua Jilid 4A Risalah Rapat Panitia Ad Hoc I Badan Pekerja MPR RI Tahun 2001 (Jakarta: Sekjen MPR RI, 2001), 213-214

${ }^{9}$ Michael Nelson, Guide To The Presidency, Second Edition, Congressional Quarterly, Washinton, Dc, 1996, Hlm 441

${ }^{10}$ Bagir Manan, Editor Moh. Fadli, Membedah Uud 1945, Universitas Brawijaya Press (Ub Press), Malang 2012. Hlm. 97-100 
akan di lakukan pemerintah. Apabila disetujui, parlemen akan menyatakan dukungan dengan memberikan mosi kepercayaan (atau dengan bahasa lain memberi kesempatan) kepada kabinet yang bersangkutan untuk bekerja. Kalau tidak disetujui kabinet baru akan mengendaikan kembali mandat kepada kepala negara.

b. Sistem (pemerintahan) Presidensil dengan ciri utama : hanya ada satu pemegang kekuasaan eksekutif (singgle executive). Kekuasaan (kedudukan) sebagai kepala negara (head of state) dan sebagai kepala pemerintahan (chief executive) ada di satu tangan. Sistem pemerintahan presidensil lazim didapati pada negara-negara republik. Ciri paling utama, pemegang kekuasaan eksekutif tidak bertanggungjawab kepada parlemen, karena itu itu tidak bergantung pada dukungan dan kepercayaan parlemen. Ada keterpisahan (separation) antara pemerintah dan parlemen. Namun dalam tatanan demokratis yang menghendaki semua kekuasaan harus bertanggungjawab (geen machtzonder vorantwoordelijkheid), walaupun tidak ada hubungan antara pemerintah dan parlemen, diadakan berdasarkan chekc and balances.

Salah satu unsur penting dalam penyelenggaraan negara atau pemerintahan adalah pertanggungjawaban dan pengawasan oleh karena jabatan Presiden Republik Indonesia adalah suatu jabatan dalam tatanan negara berdasarkan paham kerakyatan, maka harus ada pertanggungjawaban dan pengawasan ${ }^{11}$.

Sebagaimana telah di kemukakan pada bagian terdahulu, bahwa pertanggungjawaban Presiden tidak di nyatakan secara eksplisit oleh UUD NRI 1945. Namun demikian Presiden pengemban mandat tetap di tuntut untuk mempertanggungjawabkan jabatannya, khususnya kepada pemberi mandat. Dalam pasal 6A ayat (1) perubahan ketiga UUD 1945 di sebutkan bahwa Presiden dan Wakil Presiden di pilih dalam satu pasangan secara langsung oleh rakyat. Aturan konstitusi ini mengandung arti bahwa pihak yang memberikan mandat jabatan Presiden adalah rakyat. Oleh karena itu, Presiden harus mempertanggungjawabkan seluruh kegiatannya kepada rakyat. ${ }^{12}$

Persoalan kemudian yang muncul, bagaimana bentuk pertanggungjawaban Presiden kepada rakyat itu ? Berkenaan dengan masalah ini tidak ditemukan penjelasan yang rinci. Namun bila bercermin kepada Konstitusi Amerika Serikat yang memiliki kemiripan dengan UUD 1945, maka tampak bahwa Presiden tidak secara formal menyampaikan pertanggungjawabannya kepada rakyat. Rakyat dipersilahkan secara pribadi-pribadi menilai kinerja Presiden selama masa jabatannya. Penerimaan dan penolakan rakyat atas kinerja Presiden itu tidak dinyatakan secara formal, tetapi dibuktikan dengan kemungkinan rakyat untuk memilihnya kembali. Apabila rakyat menilai negatif atas kinerja Presiden, maka rakyat tidak akan memilihnya lagi sebagai Presiden pada periode berikutnya. Tetapi sebaliknya, bila rakyat menilai positip atas kinerja Presiden, maka rakyat akan memilihnya kembali sebagai Presiden di periode berikutnya.

${ }^{11}$ Bagir Manan, Lembaga Kepresidenan, Pusat Studi Hukum (PSH) Universitas Islam Indonesia dengan Gama Media, Yogyakarta, 1999, hlm 107

12 Dalam perspektif Miriam Budiardjo, pertanggungjawaban presiden kepada rakyat merupakan impementasi dari kedaulatan rakyat. Dalam teori politik tradisional rakyatlah yang memberi kekuasaan kepada pihak lain - termasuk presiden - unutk memerintah dan perintah bertanggungjawab kepada rakyat. Lihat Miriam Budiardjo, menggapai kedaulatan untuk rakyat, Mizan, Bandung, 1998. Hlm 107 
Pertanggungjawaban Presiden kepada rakyat sebagai pemberi mandat ini bukan merupakan pertanggungjawaban secara hukum, melainkan pertanggungjawaban secara politis. Artinya bahwa pertanggungjawaban Presiden kepada Rakyat tidak menimbulkan implikasi yuridis, maksudnya bahwa kalaupun pertanggungjawabannya ditolak, tapi ia tidak akan mendapat sanksi hukum yang jelas (misalnya, diberhentikan dari jabatannya), tapi secara politis itu akan mempunyai dampak ataupun pengaruh yang sangat besar sehingga mempengaruhi kredibilitas dari orang itu. Artinya bahwa apabila dengan pertanggungjawaban yang disampaikan Presiden kepada rakyat tersebut, dan ternyata rakyat menilai negatif atas kinerja Presiden, Presiden tidak bisa dituntut secara hukum. Kinerja yang negatif dari Presiden hanya akan memberikan akibat kepercayaan rakyat pada dirinya menjadi lemah, sehingga ia tidak mungkin dipilih lagi oleh rakyat menjadi Presiden. Begitu juga sebaliknya, kalau ternyata penilaian rakyat diberikan oleh rakyat kepada kinerja Presiden tersebut ternyata baik, maka rakyat akan mengangkat atau memilih kembali orang tersebut untuk menjadi Presiden kembali.

Terdapat kelemahan dalam hal pertanggungjawaban Prsiden secara langsung terhadap rakyat, karena penilaian yang yang diberikan oleh rakyat tehadap kinerja Presiden tersebut akan diwujudkan setelah Presiden menyelesaikan tugasnya selama lima tahun, yaitu dalam pemilu yang akan dilakukan ketika akan memilih Presiden berikutnya. Sehingga kalau ditengah jalan Presiden melakukan pelanggaran, maka rakyat tidak bisa berbuat apa-apa, sedangkan MPR yang adapun tidak lagi berwenang untuk meminta pertanggungjawaban terhadap Presiden.

Untuk menghindari keadaan tersebut, maka UUD 1945 telah memberikan jalan keluarnya yaitu dengan membuat ketentuan seperti yang dimuat dalam Pasal $7 \mathrm{~A}$ dan 7B, yang memberikan kemungkinan adanya pemberhentian Presiden dan/atau wakilnya dalam masa jabatannya oleh MPR berdasarkan atas usulan dari DPR.

Dari dua pasal itu tampak bahwa MPR memiliki kewenangan untuk memberhentikan Presiden setelah diusulkan oleh DPR dan mendapatkan putusan hukum dari Mahkamah Konstitusi. Kewenangan ini baru bisa dilakukan bila Presiden telah terbukti melakukan pelanggaran hukum berupa pengkhianatan terhadap negara, korupsi, penyuapan, tindak pidana berat lainnya, atau perbuatan tercela maupun apabila terbukti tidak lagi memenuhi syarat sebagai Presiden dan/atau Wakil Presiden. Namun ketentuan tersebut bukan merupakan bentuk pertanggungjawaban Presiden kepada MPR.

Mengenai prosedur pertanggungjawaban Presiden terdapat dalam pasal 7B UUD NRI 1945, dimana dalam prowses tersebut melibatkan tiga lembaga negara, yaitu DPR, MK, dan MPR. Tetapi berdasarkan menimbulkan beberapa pertanyaan yaitu : pertama, mengapa DPR yang di beri wewenang untuk mengajukan pendapat mengenai pelanggaran hukum Presiden ke MK dan mengapa hak itu jug tidak di dapat di DPD; kedua, mengapa wewenang memeriksa, mengadili, dan memeutus ada pada MK bukan pada MA; ketiga, mengapa MPR yang menjadi pemutus terakhir atas sanksi pemberhentian Presiden setelah MK membenarkan pendapat DPR tentang pelanggaran hukum Presiden.

Hak DPR untuk mengajukan pendapat tentang pelanggaran hukum Presiden merupakan rangkaian hak atas fungsi pengawasan DPR dalam 
penyelenggaraan pemerintahan dan merupakan satu-satunya lembaga negara yang di beri wewenang untuk itu sehingga secara normatif tidak akan pernah ada pertanggungjawaban dan pemberhentian Presiden tanpa di mulai dari DPR.

MK sebagai lembaga peradilan yang berwenang memeriksa, mengadili, dan memutus pendapat DPR tentang pelanggaran hukum Presiden Pasal 24C ayat (1) dan (2), yaitu :

1. MK berwenang mengadili pada tingakat pertama dan terakhir yang putusannya bersifat final untuk menguji UU terhadap UUD, memutus sengketa kewenangan lembaga negara yang kewenangannya diberikan oleh UUD, memutus pembubabaran partai politik, dan memutus perselisihan hasil pemilu;

2. MK wajib memberikan putusan atas pendapat DPR mengenai dugaan pelanggaran oleh Prsiden dan/atau Wakil Presiden menurut UUD.

Menelaah kewenangan diatas, dapat dipahami bahwa kehadiran MK sebagai salah satu institusi peradilan dalam sistem ketatanegaraan Indonesia. Wewenang MK untuk memberi putusan atas pendapat DPR tentang pelanggaran hukum Presiden adalah pelanggaran hukum dengan materi sebagaimana telah di jelaskan sebelumnya, tidak terlepas dari kedudukannya sebagai satu-satunya lembaga negara yang diberi wewenang oleh UUD sebagai penafsir konstitusi.

Walaupun demikian, sekalipun ketentuan yang termuat dalam Pasal 7A dan 7B UUD 1945 itu tidak dimaksudkan sebagai bentuk tanggungjawab Presiden kepada rakyat, tapi secara maknanya bahwa di sana tersirat adanya sifat pertanggungjawaban Presiden. Sebab, meskipun tidak secara tegas UUD 1945 menyebutkannya sebagai bentuk pertanggungjawaban Presiden, tapi ketentuan tersebut merupakan implementasi dari adanya sebuah pengawasan. Menurut logika, apalah artinya sebuah pengawasan apabila hasil dari pengawasan itu tidak ditindaklanjuti. Hal tersebut sesuai dengan apa diungkapkan oleh I Gede Pantja Astawa bahwa dalam makna kontrol itu sendiri terkandung asas pertanggungjawaban. ${ }^{13}$

Pelaksanaan hak dan fungsi DPR yang terkait dengan forum pemakzulan itu sebagaimana diatur dalam Pasal 20A ayat (1) dan (2) UUD 1945 sebagai berikut:

1. Dewan Perwakilan Rakyat memiliki fungsi legislasi, fungsi anggaran, dan fungsi pengawasan.

2. Dalam melaksanakan fungsinya, selain hak yang diatur dalam pasal-pasal lain dalam Undang-Undang Dasar ini, Dewan Perwakilan Rakyat mempunyai hak interpelasi, hak angket, dan hak menyatakan pendapat.

Fungsi pengawasan adalah fungsi DPR dalam melakukan pengawasan terhadap kebijakan dan pelaksanaan pemerintahan dan pembangunan oleh Presiden (Pemerintah) Pendapat DPR tersebut berisi tentang pernyataan DPR bahwa Presiden dan Wakil Presiden melakukan pelanggaran hukum berupa pengkhianatan terhadap negara, korupsi, penyuapan, tindak pidana berat lainnya, atau perbuatan tercela dan/atau bahwa Presiden dan/atau Wakil Presiden tidak lagi memenuhi syarat sebagai Presiden dan/atau Wakil Presiden.

Jadi menurut penululis perlu dirumuskan perihal pertanggungjawaban Presiden kepada rakyat melalui lembaga negara yang sudah ada dengan

${ }^{13}$ I Gede Pantja Astawa, Op.Cit., Hlm 25 
memperhatikan asas cheks and balances bukun untuk mengembalikan kepada sistem pemerintahan parlementer, tetapi pertanggungjawaban yang dapat di terima oleh masyarakat sebagai pemberi mandat kepada siapapun yang menduduki jabatan Presiden Republik Indonesia melalui DPR. Akan lebih baik bila pengaturan tersebut di tuangkan dalam UUD NRI 1945 sehingga pengaturan didalam UUD 1945 dalam pasal 7A dan 7B tidak lagi multi tafsir. Sehingga masyarakatpun mengetahui apa yang di lakukan oleh Presiden dengan kekuasaan begitu besar yang melekat pada jabatannya dengan adanya pertanggungjawaban dan penilaian oleh DPR dengan kewenangan pengawasannya di luar mekanisme impeachment. Sedangkan prosedur Impeachment tetap dilakukan sebagaimana yang telah termaktub dalam UUD saat ini.

Apabila dari hasil pertanggungjawaban yang di berikan oleh Presiden tersebut kepada DPR kemudian terdapat hal-hal yang berimplikasi kepada Impeachment dengan palanggaran-pelanggaran yang telah di sebutkan seperti pengkhianatan terhadap negara, korupsi, penyuapan, perbuatan tercela lainnya maka mekanisme Impeac-nya melalui prosedur yang telah di tentukan, dimulai dari usulan DPR kepada MK, MK memutuskan benar atau tidak nya telah dilakukan perbuatan sebagaiamana di maksud, kemudian keputusan tersebut di serahkan kepada MPR untuk proses Impeachment-nya.

Pertanggungjawaban Presiden dalam masa jabatannya yang penulis maksud disini hanya berada dalam tatanan hukum pertanggungjawaban Presiden kepada rakyat melalui DPR untuk lebih efektif dan efisien. Pertanggungjawaban itu kemudian di nilai oleh DPR sebagai political representation dari rakyat dalam pemerintahan. Tentunya terdapat punishment dan reword terhadap apa yang telah di lakukan oleh Presiden selama masa jabatannya.

Sebagaiman pendapatnya Bagir Manan yang telah di kemukakan di awal, bahwa jabatan Presiden RI adalah suatu jabatan dalam tatanan negara berdasarkan paham kerakyatan. Karena itu harus ada pertanggungjawaban dan pengawasan. Oleh karena masalah pertanggungjawaban Presiden itu sangat penting, maka seharusnya persoalan tersebut diatur dengan tegas dan jelas serta rinci didalam peraturan perundang-undagan yang berlaku. Bahkan akan lebih baik bila masalah pertanggung jawaban Presiden di muat didalam batang tubuh UUD 1945. Dengan kejelasan itu, maka fungsi pengawasan yang di lakukan oleh DPR akan lebih mudah untuk dilaksanakan.

2. Bentuk alternatif pertanggungjawaban Presiden

a. Pertanggungjawaban Presiden Sebelum Amandemen UUD 1945

Pada saat menyusun UUD NRI 1945 (BPUPKI dan PPKI), the framersof the constitution yang sekaligus adalah the founding fathers negara RI, bertolak dari sejumlah kosnep sebagai dasar sistem pemerintahan, antara lain ${ }^{14}$ :

1. Negara Indonesia tidak disusun atas dasar paham liberal-individualisme yang di anggap melahirkan kapitalisme-imperialisme dan mengakibatkan penjajahan terhadap bangsa lain termasuk penjajahan di Indonesia. paham liberalisme-individualisme menurut para pembentuk negara RI mencakup semua aspek kehidupan berbangsa dan berngara (politik, ekonomi, dan sosial) termasuk sistem pemerintahan parlementer. Dalam pidato tanggal 31 Mei 1945 Soepomo mengatakan "menolak dasar individualisme berarti

${ }^{14}$ Ibid,. Hlm 109-110 
menolak juga sistem parlementarisme". apabila dasar ini dilihat dari sisi lain (the other side of a coin) dapat pula diberi makna setiap bentuk kapitalismeindividualisme bertentangan dengan bangunan Indonesia merdeka, termasuk sistem pemerintahannya.

2. Pemerintahan negara dijalankan Presiden dan Wakil Presiden yang di pilih MPR dan bertanggung jawab kepada MPR. Penjelasan UUD 1945 menyebutkan "Concentration Of Power And Responcibility Upon The President". Mohammad Hatta dengan tegas menyebutkan sebagai sistem presidensil

3. Presiden adalah mandataris MPR, tunduk (teks asli : bertunduk) dan bertanggung jawab kepada MPR. Presiden tidak neben tetapi untergoerdnet terhadap MPR.

4. Presiden apabila sungguh-sungguh melanggar haluan negara dapat diberhentikan MPR.

5. Presiden tidak bertanggung jawab kepada DPR, dan tidak dapat membubarkan DPR.

Artinya sebelum amandemen UUD 1945, MPR menjadi lembaga negara yang superior. Yang berwenang memilih dan memberhentikan Presiden, serta presiden tuduk dan bertanggungjawab kepada MPR. Maka dari situ dapat dilihat bahwasannya mekanisme kontrol pada masa sebelum amandemen UUD 1945 cukup bagus karena MPR menjadi lembaga negara tempat presiden bertanggungjawab selama masa jabatannya. Terlepas dari perdebatan kewenangan MPR memilih dan mengangkat Presiden dan Wakil Presiden.

Dengan adanya pertanggungjawaban demikian, maka jalannya pemerintahan dapat di kontrol oleh MPR, juga dapat melakukan evaluasi terhadap rencana, program dan kebijakan yang dibuat oleh pemerintah. Yang jika tidak sesuai dapat dijatuhkan sanksi oleh MPR.

Dampak dari keberadaan pertanggungjawaban presiden juga bisa diberhentikannya Presiden terkait dari jabatannya ketika tidak dapat mempertanggungjawabkan apa yang terjadi di masa pemerintahannya. Sebagai contoh diatas dinyatakan selain persoalan G.30.S/PKI Presiden Soekarno juga di berhentikan karena persoalan kemerosotan akhlak. Itupun diera sistem pemerintahan yang parlementer yang kekuasaan kepala negara dan kepala pemerintahannya terpisah, apalagi sekarang yang kekuasaan Presidennya begitu luas sebab sebagai singgle exxecutuve (Presiden sebagai kepala negara dan kepala pemerintahan).

Sebelum perubahan UUD 1945 MPR telah memakzulkan dua Presiden RI, yakni Ir. Soekarno, berdasarkan TAP MPRS Nomor XXXIII/MPRS/1967 dan K.H. Abdurrahman Wahid. Pemakzulan Gus Dur berdasarkan TAP MPR Nomor II/MPR/2001. Majelis Permusyawaratan Rakyat Sementara (MPRS) pada tahun 1967 setelah memorandum Dewan Perwakilan Rakyat Gotong Royong (DPR-GR, sebagaimana yang dapat dibaca dalam pertimbangan pemakzulan Presiden Soekarno, MPRS memakzulkan presiden karena pidato Nawaksara pada tanggal 22 Juni 1966 maupun surat pelengkap Nawaksara tanggal 10 Januari 1967 tidak secara jelas mempertanggungjawabkan kebijaksanaan presiden mengenai 
pemberontakan kontra revolusi G.30.S/PKI beserta epilognya, kemunduran ekonomi beserta kemunduran akhlak. ${ }^{15}$

Kasus pemakzulan Presiden seperti yang menimpa Soekarno dan Abdulrahman Wahid, menunjukan dan membenarkan kalau kedudukan Pressiden bukanlah kedudukan yang kebal dari pertanggungjawaban Yuridis ataupun politis. Presiden bisa saja dilengserkan atau di copot dari jabatannya. Tidak ada yang kebal hukum atau mempunyai hak imunitas di negara hukum ini. Siapapun orangnya, termasuk Presiden atau Wakil Presiden bisa di berhentikan dari jabatannya. ${ }^{16}$

\section{b. Pertanggungjawaban Presiden Pasca Amandemen UUD 1945}

Chekc and balances adalah salah satu konsep yang mendasari perubahan UUD 1945. Ditinjau dari sudut pandang hukum (legal framework) ada tiga cara yang ditempuh oleh perubahan UUD 1945 untuk meniadakan executive heavy dan membangun chekc and balances. ${ }^{17}$

Pertama, mengurangi kekuasaan Presiden dan di pindahkan menjadi kekuasaan DPR. Misalnya kekuasaan membentuk UU. Kedua, pembatasan cara menjalankan kekuasaan Presiden, bukan kekuasaan yang dibatasi tetapi cara menjalankan kekuasaan. Misalnya Presiden dan Wakil Presiden dapat di berhentikan dalam masa jabatan dengan alasan melanggar hukum (pidana), melakukan perbuatan tercela, tidak lagi memenuhi syarat Presiden dan atau Wakil Presiden. ${ }^{18}$ Atau pengangkatan duta atau penerimaan duta negara lain, memberikan amnesti dan abolisi wajib memperhatikan pertimbangan DPR. ${ }^{19}$ Ketiga, memperbesar kekuasaan DPR. Selain memindahkan kekuasaan Presiden menjadi kekuasaan DPR, membagi kekuasaan Presiden dengan DPR, adapula penambahan dan penegasan hak-hak inheren yang memang sudah dimiliki DPR. Penambahan hak antara lain hak interplasi, hak angket, dan hak menyatakan pendapat, yang sebelum perubahan hak-hak tersebut dianggap sebagai pranata parlementer.

Eksekutif kuat (too strong) ini melahirkan pemerintahan yang otoritarian (diktator), tirani, sementara eksekutif lemah (too weak) melahirkan pemeritahan yang tidak efektif. Sama-sama akan membuat cita-cita kesejahteraan umum, kemakmuran, keadilan sosial, makin jauh dari kenyataan.

Didalam pasal 7A dan Pasal 7B UUD 1945 tidak di rumuskan dengan jelas dan terperinci perihal pertanggungjawaban Presiden, karena muatan pasal tersebut mengarah kepada peranata proses pemakzulan presiden (impeachment). Hamdan Zoelva dalam bukunya pemakzulan presiden di Indonesia mengungkapkan perubahan UUD 1945 menentukan secara lebih rinci alasan-alasan maupun mekanisme pemakzulan Presiden sebagaimana di atur dalam pasal 7A dan pasal 7B UUD 1945. Pasal 7A UUD 1945 menentukan bahwa seorang presiden dapat diberhentikan dalam masa jabatannya oleh MPR apabila terbukti telah melakukan

${ }^{15}$ Lihat Diktum A. Menimbang Ketetapan Majelis Permusyawaratan Rakyat Sementara Republik Indonesia No. Xxxiii/Mprs/1967 Tentang Pencabutan Kekuasaan Pemerintahan Negara Dari Presiden Soekarno

16 Abdul Wahid, 2014. Independensi Mahkamah Konstitusi Dalam Proses Pemakzulan Presiden dan/atau Wakil Presiden, Jurnal Konstitusi, Volume 11, Nomor 4, Desember 2014.

${ }^{17}$ Bagir Manan, Editor Moh. Fadli, Membedah Uud 1945, Universitas Brawijaya Press (Ub Press), Malang 2012. Hlm.117-119

${ }^{18}$ Pasal 7a Uud 1945

${ }^{19}$ Pasal 13 Dan 14 Uud 1945 
pelanggaran hukum berupa pengkhianatan terhadap negara, korupsi, penyuapan, tindak pidana berat lainnya atau perbuatan tercela ataupun jika terbukti tidak lagi memenuhi syarat sebagai Presiden.

Sementara itu pasal 7B mengatur mekanisme pemakzulan Presiden, yaitu menentukan bahwa usul pemberhentian Presiden dapat diajukan oleh DPR kepada MPR, hanya dengan terlebih dahulu mengajukan permintaan kepada Mahkamah Konstitusi untuk memeriksa, mengadili, dan memutus pendapat DPR behwa Presiden telah melakukan pelanggaran hukum berupa pengkhianatan terhadap negara, korupsi, penyuapan, tindak pidana berat lainnya atau perbutan tercela maupun apabila terbukti tidak lagi memenuhi syarat sebagai Presiden.

Usul pemakzulan Presiden oleh DPR hanya dapat di lakukan melalui rapat yang di hadiri paling kurang $2 / 3$ anggota DPR dan di setujui oleh paling kurang 2/3 anggota DPR yang hadir. ${ }^{20}$ Adapun MPR hanya dapat memakzulkan presiden melalui rapat yang di hadiri paling kurang 3/4 anggota MPR yang hadir. ${ }^{21}$

Penguatan sistem presidensial tersebut dilakukan dengan memberikan jaminan konstitusional jabatan presiden fix term lima tahun dan presiden di pilih langsung oleh rakyat. Pada sisi lain untuk menjamin jabatan presiden fix term diatur pula alasan dan mekanisme pemakzulan presiden dipersulit. Jika sebelumnya mekanisme pemakzulan presiden melalui pertanggungjawaban politik presiden di hadapan MPR yang berdasarkan alasan-alasan politis dan kebijakan, maka setelah perubahan Undang-Undang Dasar mekanisme pertanggungjawaban presiden dilakukan dilakukan melalui mekanisme pemakzulan yang didasarkan pada alasan-alasan pelanggaran hukum dan/atau tidak lagi memenuhi syarat sebagai presiden. Perubahan norma dasar ini sangat terkait dengan perubahan cara pemilihan presiden yang sebelumnya dilakukan MPR, menjadi pemilihan langsung dilakukan rakyat. Pemikiran inilah yang mendasari perubahan mekanisme pemakzulan Presiden menurut UUD $1945 .{ }^{22}$

Pertanggungjawaban Presiden pasca amandemen UUD 1945 adalah pertanggungjawaban hukum dengan pranata impeachment yang tebatas pada beberapa hal seperti, pengkhianatan terhadap negara, korupsi, penyuapan, tindak pidana berat lainnya, atau perbuatan tercela ataupun jika terbukti tidak lagi memenuhi syarat sebagai presiden. Pertanggungjawaban ini merupakan pertanggungjawaban moral cendrung terbatas. Karena dikhawatirkan adanya politisasi dalam pemakzulan presiden. Diluar daripada itu masih terdapat banyak hal yang di lakuakn oleh presiden berdasarkan kewenangan dan fungsi yang melakat pada jabatan presidn yang juga dapat di mintai pertanggungjawaban secara hukum, sehingga arah kebijakan dalam pranata sistem presidensil yang berlandaskan hukum dan konstitusi bisa di ukur capaian dan dapat lebih efektif dan efisien setiap kebijakan yang di lakukan dalam rangka membangun suatu pemerintahan yang melindungi segenap bangsa dan seluru tumpah darah Indonesia dan untuk memajukan kesejahteraan umum, mencerdaskan kehidupan

${ }^{20}$ Uraian panjang yang di tulis oleh Nandang Alamsyah Deliarnoor didalam disertasinya yang berjudul "Forum Privilegiatum Dalam Negara Hukum Berdasarkan UUD 1945”, Program Pascasarjana Universitas Padjajaran, Bandung 2006, juga tidak menemukan adanya aturan perundang-undangan atau praktik keputusan peradilan oleh forum Privilegiatum yang memakzulkan pejabat yang di adili melalui forum Privilegiatum..

${ }^{21}$ Pasal 7B ayat (7) UUD 1945

${ }^{22}$ Hamdan Zoelva, Op., Cit., Hlm 96 
bangsa, dan ikut melaksanakan ketertiban dunia yang berdasarkan kemerdekaan, perdamaian abadi dan keadilan sosial (sebagaimana tujuan negara yang termaktub di dalam preambule UUD 1945).

\section{c. Alternatif Pertanggungjawaban Presiden}

Dalam proses penyusunan konsep pemakzulan Presiden Jimly $^{23}$ kembali menegaskan usulan tim ahli tentang alasan-alasan dan mekanisme pemakzulan presiden. Ada tiga alasan pemakzulan presiden, yaitu; a) pelanggaran sumpah jabatan, b) pelanggaran hukum berupa pengkhianatan terhadap negara, dan c) tidak lagi memenuhi syarat sebagai presiden. Kemudian Tim Ahli juga menegaskan proses peradilan pidana terhadap presiden hanya dapat dilakukan setelah yang bersangkutan menjadi warga negara biasa. ${ }^{24}$ Alasan pemakzulan ini menurut Jimly konsisten dengan sistem presidensial yang pada prinsipnya fix term, lima tahun. Presiden tidak bisa di berhentikan dalam jabatannya dengan alasan politis seperti yang terjadi sekarang, misalnya pelanggaran halauan negara.

Lebih lanjut pelanggaran sumpah jabatan, Jimly ${ }^{25}$ menegaskan persis sama dengan bunyi sumpah jabatan dalam UUD 1945. Sementara yang di maksud pelanggaran hukum disini adalah pelanggaran hukum pidana, tetapi di batasi yang tertentu saja yaitu pengkhianatan terhadap negara (treason), korupsi, penyuapan, dan perbuatan tercela. Lalu apa bedanya pelanggaran sumpah jabatan dengan pelanggaran hukum pidana, padahal pelanggaran hukum pidana sudah pasti merupakan pelanggaran sumpah jabatan. Dalam hal itu Jimly menegaskan hal itu hanya penegasan saja. Sumpah jabatan itu tidak selalu berarti harus pelanggaran hukum seperti yang di rumuskan dalam berbagai konstitusi negara di dunia. Pelanggaran hukum lebih merupakan individual responcibility sedangkan pelanggaran sumpah jabatan berkaitan dengan jabatan. Akan tetapi pelanggaran sumpah jabatan ${ }^{26}$ merupakan pelanggaran hukum juga, karena sumpah jabatan tercantum dalam UUD yang dengan sendirinya dapat bermakna pelanggaran terhadap ketentuan hukum, yaitu pelanggaran terhadap UUD.

Memperlihatkan rumusan sumpah jabatan dalam UUD 1945, alasan pelanggaran sumpah jabatan menjadi sangat luas, sumpah jabatan menegaskan sumpah/janji presiden untuk memenuhi kawajiban presiden Republik Indonesia denagan sebaik-baiknya dan seadil-adilnya, memegang teguh Undang-Undang Dasar dan menjalankan segala Undang-Undang dan peraturanya dengan seluruslurusnya serta berbakti kepada nusa dan bangsa. "peraturan" disini tidak terbatas, bisa UUD bisa UU, Peraturan Pemerintah, Peraturan Presiden, Peraturan Daerah, bahkan bisa peraturan-peraturan lainnya. Sehingga alasan pelanggaran sumpakh jabatan memperluas alasan pemakzulan Presiden menjadi tidak terbatas. Seperti di kemukakan Jimly ${ }^{27}$ pelanggaran terhadap sumpah jabatan termasuk pelanggaran terhadap keputusan Presiden atau pelanggaran terhadap UU pajak. Jika presiden

\footnotetext{
${ }^{23}$ Rapat Pleno PAH I, 29 Mei 2001

${ }^{24}$ Majelis Permusyawaratan Rakyat Republik Indonesia, Buku Kedua Jilid 4A, Op.Cit., $\mathrm{Hlm} .213$

${ }^{25} \mathrm{Ibid}, \mathrm{Hlm} 214$

${ }^{26}$ Sumpah jabatan Presiden adalam UUD 1945, selengkapnya berbunyi sebagai berikut : "Demi Allah saya bersumpah akan memenui kewajiban Presiden Republik Indonesia dengan sebaik-baiknya dan seadil-adilnya, memegang teguh Undang-Undang Dasar dan menjalankan segala Undang-Undang dan peraturannya dengan selurus-lurusnya serta berbakti kepada nusa dan bangsa.

${ }^{27}$ Ibid.
} 
tidak menegakan UU Pajak seperti yang di perintahkan UU, maka dapat menjadi alasan untuk memakzulkan Presiden. ${ }^{28}$

Dengan demikian formulasi regulasi yang mengatur berkenaan dengan stabilitas (keseimbangan) antara presiden dengan DPR, agar tidak ada lembaga yang strong ataupun weak. Dan perlu adanya reformulasi untuk meminta pertanggungjawaban Presiden selama memimpin oleh DPR. Dengan tidak merendahkan kekuasaan eksekutif.

Pertanggungjawaban tersebut diberikan langsung oleh Presiden kepada DPR (mandatari rakyat di pemerintahan) melalui sidang paripuran istimewa dewan di akhir masa sidang tahunan dengan sifat terbuka untuk umum bahkan dapat di publis kepada khalayak melalui media masa. Agar penggunaan APBN dan kewenangan Presiden selama satu tahun Anggran dapat di ketehui oleh publik, dan DPR dapat memberikan penilaian yang efektif substansional sesuai kewenangan dan prosedur yang ada, bahkan pemakzulan sebagai Ultimum Remedium dalam mengawasi kinerja Presiden. Dengan kriteria pelanggaran yang dilakukan sesuai pasal 7A dan tidak terbatas dalam pasal tersebut tetapi dapat melampaui dan sesuai dengan kewenangan yang di miliki dan di jalankan oleh Presiden segai kepala negara (head of state) dan kepala pemerintahan (chief of executife) dalam sistem Presidensil. DPR tidak memberikan penilaian berdasarkan like and dislike koalisi partai di pemerintahan, tetapi pure sebagai pemegang mandatari political representation by the people.

Penempatan pertanggungjawaban jabatan Presiden tidak lepas dari pandangan konsep jabatan sebagai Pribadi dalam hukum tata negara yang dikonsepsi oleh Loegemann. Senada dengan Kelsen dan Dennis F. Thomson bahwa individulah yang memberi bentuk dan isi dari kekuasaan organisasi, maka atas nama organisasi, individu mempertanggungjawabkan tindakan organisasi yang dilakukan oleh aktor organisasi, termasuk mempertanggungjawabkan diri atas tindakan selama dalam masa jabatan, sehingga pertanggungjawaban jabatan Presiden dalam pengertian Pasal 7A terkait dengan bentuk hukuman berupa pemberhentian dari jabatan Presiden. Hal demikian dianut pula oleh Konstitusi Amerika Serikat.

Dikatakan pertanggungjawaban jabatan karena individu pejabat memberikan pertanggungjawaban dalam kualitas jabatan, baik dalam menjalankan fungsi organisasi maupun bertindak di luar fungsi organisasi. Asumsi untuk mengatakan pertanggungjawaban jabatan karena inti dari proses yang berlangsung dalam Pasal 7A UUD 1945 adalah pemberhentian dari jabatan sebagai Presiden Republik Indonesia. Berangkat dari tesis strukturalis yang menyangsikan pertanggugjawaban individu pejabat atas tindakan yang dilakukan oleh karena perintah dan kepentingan organisasi, artinya sepanjang tindakan pejabat dalam koridor kepentingan organisasi, bagi strukturalis tidak membenarkan adanya pertanggungjawaban individu sekalipun tindakan tersebut dapat dipersalahkan secara hukum atau dengan logika sederhana, Presiden dibenarkan membunuh demi kepentingan negara dengan alasan-alasan pemaaf sebagaimana lazim dalam hukum pidana.

Herbert J. Spiro ${ }^{29}$ tidak membenarkan hal tersebut dengan mengajukan empat syarat pejabat publik untuk dapat dimintai pertanggungjawaban atas

${ }^{28}$ Hamdan Zoelva, Op. Cit, Hlm. 102-104 
tindakannya antara lain; resource, knowledge, chooices, and purpouse, sehingga sekalipun Presiden bertindak dalam menjalankan Pemerintahan, maka kepada individu pejabat yang memberi isi kepada kekuasaan dan wewenang pertanggungjawaban melekat karena empat syarat tadi, yakni memiliki kemampuan karena suatu kekuasaan, memiliki pengetahuan atas keputusan yang diambil, mempunyai pilihan--pilihan di antara keputusan-keputusan yang hendak diambil, mengetahui maksud dari suatu keputusan.

Pandangan Spiro dapat dijadikan dasar untuk meminta pertanggungjawaban Presiden sekalipun dalam menjalankan fungsi-fungsi Pemerintahan, ketika ada suatu kebijakan Pemerintahan yang bersifat vital dan strategis dan membahayakan bagi rakyat dan keselamatan bangsa dan negara. Konteksnya terdapat dalam ketentuan Pasal 7A khususnya "...terbukti tidak lagi memenuhi syarat sebagai Presiden..." yang dapat ditafsirkan sebagai pelanggaran hukum dalam arti luas, seperti tidak mampu memenuhi kewajiban sebagai Presiden Republik Indonesia, melanggar UUD dan UU, serta peraturan lainnya, dan tidak berbakti kepada nusa dan bangsa, merupakan pengguguran atas tesis strukturalis bagi pertanggungjawaban Presiden di Indonesia. Kesalahan struktur atau dalam bahasa Perancis faute de service, sedangkan kategori pelanggaran hukum berupa pengkhianatan terhadap negara, korupsi, penyuapan, tindak pidana berat lainnya atau perbuatan tercela, merupakan tindakan Presiden di luar kepentingan negara dan jabatan, sehingga perbuatan tersebut merupakan kualifikasi kejahatan sebagai individu dan dapat dipersalahkan secara hukum untuk selanjutnya dapat dituntut di depan pengadilan seperti rakyat pada umumnya setelah diberhentikan dari jabatan. Kesalahan individu dalam jabatan biasa disebut dengan faute de personelle.

Berangkat dari cara berpikir di atas, maka bentuk pertanggungjawaban Presiden menurut UUD 1945 khususnya Pasal 7A adalah bentuk pertanggung jawaban hukum yang terdiri dari pertanggungjawaban hukum pidana berupa pengkhianatan terhadap negara, korupsi, penyuapan, tindak pidana berat lainnya atau perbuatan tercela dan pertanggungjawaban hukum kebijakan Pemerintahan (policy) yakni terbukti tidak lagi memenuhi syarat sebagai Presiden berupa gagal mengemban amanah rakyat dan tidak dapat memenuhi kewajibannya sebagai Presiden, melanggar UUD dan tidak melaksanakan UU dan peraturan lainnya dengan sebaik-baiknya dan seadil-adilnya, serta tidak berbakti kepada nusa dan bangsa.

Ada tiga hal pokok yang memberi bentuk terhadap pertanggungjawaban Presiden antara lain; pertama, pelanggaran hukum yang bersifat kriminal; kedua, pelanggaran hukum yang bersifat kebijakan; dan ketiga, jabatan Presiden. Hal tersebut menunjukkan bahwa bentuk pertanggungjawaban Presiden setelah amandemen UUD 1945 merupakan bentuk pertanggungjawaban hukum ketatanegaraan yang terdiri dari; pertama, pertanggungjawaban hukum pidana yang dilakukan oleh Presiden di luar kepentingan jabatan dan organisasi; kedua, pertanggungjawaban hukum atas tindakan Presiden dalam menjalankan Pemerintahan negara. Pertanggungjawaban hukum tersebut dilakukan dalam masa jabatan, sehingga sanksi maksimal atas perbuatan tersebut adalah pemberhentian atau pemecatan dari jabatan sebagai Presiden, kecuali pertanggungjawaban hukum

${ }^{29}$ Herbert J. Spiro, Responsibility In Government : Theory and Practice, van Nostrand Reinhold Company, New York Cicinnanti Toronto, London, Melbourne, 1969, hlm. 46.

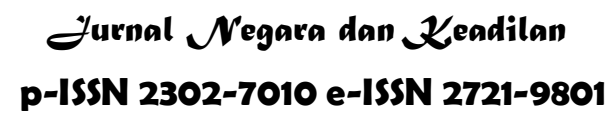


pidana akan ditindaklanjuti dalam peradilan umum sebagai masyarakat biasa setelah pertanggungjawaban jabatan selesai dilaksanakan, sehingga bentuk pertanggungjawaban Presiden bersifat quasi-kriminal (quasi-criminal) karena bentuk pertanggungjawabannya berada antara perbuatan pidana, dan jabatan dalam hukum ketatanegaraan. Berangkat dari uraian di atas, penulis cenderung untuk menyebutnya sebagai bentuk pertanggungjawaban hukum dalam sistem ketatanegaraan yang unsurnya terdiri dari pertanggungjawaban hukum pidana, pertanggungjawaban politik, dan pertanggungjawaban jabatan.

Perbuatan Presiden dalam kapasitas fungsi struktur (jabatan) untuk menyelenggarakan tugas-tugas pelayanan publik, baik melakukan tindakan maupun tidak melakukan yang seharusnya dilakukan dalam rangka kepentingan masyarakat, bangsa dan negara, sehingga menimbulkan implikasi yang merugikan bahkan membahayakan kehidupan ketatanegaraan; yang menyebabkan seorang Presiden melanggar Pasal 7A khususnya ketentuan "...tidak lagi memenuhi syarat sebagai Presiden..." juncto Pasal 9 tentang sumpah dan janji jabatan, tetapi belum tentu pelanggaran hukum dalam kualifikasi kebijakan (policy) yang salah dalam penyelenggaraan pemerintahan memenuhi unsur perbuatan pidana sebagaimana ketentuan Pasal 7A khususnva ketentuan "...pengkhianatan terhadap negara, korupsi, penyuapan, tindak pidana berat lainnya...".Oleh karena itu, pertanggungjawaban demikian penulis menyebutnya sebagai pertanggungjawaban relatif, dengan unsur-unsur sebagai berikut; pertama, kesalahan dan atau lalai dalam mengeluarkan kebijakan pemerintahan yang berimplikasi pada instabilitas kehidupan masyarakat, berbangsa dan bernegara belum tentu memenuhi unsur perbuatan pidana sebagaimana ketentuan Pasal 7A UUD 1945; kedua, oleh karena itu sanksi maksimal diberhentikan dari jabatan apakah secara terhormat atau tidak terhormat tergantung pada kondisi mana Presiden diberhentikan dan kepadanya belum tentu dapat dituntut secara pidana.

Bentuk pertanggungjawaban Presiden diakhir masa jabatan dapat dilakukan dengan beberapa hal, ini berangkat dari cara berpikir di atas, maka bentuk pertanggungjawaban Presiden menurut UUD 1945 khususnya Pasal 7A adalah bentuk pertanggung jawaban hukum yang terdiri dari pertanggungjawaban hukum pidana berupa pengkhianatan terhadap negara, korupsi, penyuapan, tindak pidana berat lainnya atau perbuatan tercela dan pertanggungjawaban hukum kebijakan Pemerintahan (policy) yakni terbukti tidak lagi memenuhi syarat sebagai Presiden berupa gagal mengemban amanah rakyat dan tidak dapat memenuhi kewajibannya sebagai Presiden, melanggar UUD dan tidak melaksanakan UU dan peraturan lainnya dengan sebaik-baiknya dan seadiladilnya, serta tidak berbakti kepada nusa dan bangsa.

Dalam pemberian pertanggungjawaban terhadap apa yang telah di lakukan oleh Presiden dapat dilakukan diakhir satu kali masa akhir penggunaan APBN atau diberikan setiap setahun sekali di akhir tahun agar menghindari pertanggungjawaban tersebut sebaai pertanggungjawaban politis kalau di berikan di akhir periode jabatan, sehingga pertanggungjawaban tersebut betul-betul pertanggungjawaban hukum yang di lakukan oleh Presiden. Pemberian pertanggungjawaban tersebut berkaitan dengan semua tugas dan fungsi yang melekat dalam jabatan Presiden. Khususnya pertanggungjawaban tersebut wajib memuat pertanggungjawaban hukum perbuatan pemerintah (policy) yakni terbukti tidak lagi memenuhi syarat sebagai Presiden berupa gagal mengemban amanah 
rakyat dan tidak dapat memenuhi kewajibannya sebagai Presiden. Hal ini bertujuan agar kewenangan yang besar dari jabatan Presiden (baik sebagai head of state maupun chief of eksecutife) wajib di pertanggungjawabkan oleh siapapun yang mengisi jabatan dan menjalankan roda organisasi dalam jabatan tersebut agar setiap policy yang di ambil lebih terarah dan dapat di rasakan kebijakan tersebut oleh seluruh rakyat Indonesia, atau sebagai bahan evaluasi menuju pembangunan tatanan masyarakat madani juga sejahtera (dalam bahasa yang lebih populer dikenal dengan istilah Indonesia Emas), sebagai mana amanah konstitusi UUD Negara Republik Indonesia Tahun 1945.

\section{PENUTUP}

Sekalipun ketentuan yang termuat dalam Pasal 7A dan 7B UUD 1945 itu tidak dimaksudkan sebagai bentuk tanggungjawab Presiden kepada rakyat, tapi secara maknanya bahwa di sana tersirat adanya sifat pertanggungjawaban Presiden. Sebab, meskipun tidak secara tegas UUD 1945 menyebutkannya sebagai bentuk pertanggungjawaban Presiden, tapi ketentuan tersebut merupakan implementasi dari adanya sebuah pengawasan. Menurut logika, apalah artinya sebuah pengawasan apabila hasil dari pengawasan itu tidak ditindaklanjuti. Hal tersebut sesuai dengan apa diungkapkan oleh I Gede Pantja Astawa bahwa dalam makna kontrol itu sendiri terkandung asas pertanggungjawaban.

Bentuk pertanggungjawaban Presiden diakhir masa jabatan dapat dilakukan dengan beberapa hal ini. Berangkat dari cara berpikir di atas, maka bentuk pertanggungjawaban Presiden menurut UUD 1945 khususnya Pasal 7A adalah bentuk pertanggung jawaban hukum yang terdiri dari pertanggungjawaban hukum pidana berupa pengkhianatan terhadap negara, korupsi, penyuapan, tindak pidana berat lainnya atau perbuatan tercela dan pertanggungjawaban hukum kebijakan Pemerintahan (policy) yakni terbukti tidak lagi memenuhi syarat sebagai Presiden berupa gagal mengemban amanah rakyat dan tidak dapat memenuhi kewajibannya sebagai Presiden, melanggar UUD dan tidak melaksanakan UU dan peraturan lainnya dengan sebaik-baiknya dan seadiladilnya, serta tidak berbakti kepada nusa dan bangsa.

Dalam pemberian pertanggungjawaban terhadap apa yang telah di lakukan oleh Presiden dapat dilakukan diakhir satu kali masa akhir penggunaan APBN atau diberikan setiap setahun sekali di akhir tahun agar menghindari pertanggungjawaban tersebut sebaai pertanggungjawaban politis kalau di berikan di akhir periode jabatan, sehingga pertanggungjawaban tersebut betul-betul pertanggungjawaban hukum yang di lakukan oleh Presiden.

\section{DAFTAR PUSTAKA}

Jimly Asshiddiqie, Et Al, 2006. Gagasan Amandemen UUD 1945 Dan Pemilihan Presiden Secara Langsung, Jakarta : Sekretaris Jendral Dan Kepaniteraan Mahkamah Konstitusi RI.

Sri Soemantri, 2014, Hukum Tata Negara Indonesia Pemikiran Dan Pandangan, Bandung, Pt Remaja Rosdakarya.

Bagir Manan, 1999 lembaga kepresidenan, Yogyakarta, Pusat Studi Hukum (PSH) Universitas Islam Indonesia dengan Gama Media.

---------, Editor Moh. Fadli, 2012, Membedah Uud 1945, Malang, Universitas Brawijaya Press (Ub Press) 
Yusril Ihza Mahendra, 1996, Dinamika Tata Negara Indonesia,Jakarta, Gema Insani Press.

Herbert J. Spiro, 1969 Responsibility In Government : Theory and Practice, van Nostrand Reinhold Company, New York Cicinnanti Toronto, London, Melbourne.

Miriam Budiardjo, 1998, menggapai kedaulatan untuk rakyat, Bandung, Mizan.

Muhammad Yamin, 1960, Pembahasan Undang-Undang Dasar 1945, Jilid Keempat, Penerbit Yayasan Prapanca.

Hamdan Zoelva, 2011, Pemakzulan Presiden Di Indonesia, Jakarta, Sinar Grafika.

Margarito Kamis, 2014 Pembatasan Kekuasaan Presiden, Pergeseran Kekuasaan Presiden Pasca Amandemen UUD 1945, Malang, SETARA PRESS.

Michael Nelson, 1966, Guide To The Presidency, Second Edition, Congressional Quarterly, Washinton, Dc.

Frits Marannu Dapu, 2014 Pertanggungjawaban Presiden Menurut Sistem Ketatanegaraan, lex et Societatis Vol II/No. 7/Ags/2014

Abdul Wahid, 2014. Independensi Mahkamah Konstitusi Dalam Proses Pemakzulan Presiden dan/atau Wakil Presiden, Jurnal Konstitusi, Volume 11, Nomor 4, Desember 2014.

Republik Indonesia, Undang-undang Dasar Negara Republik Indonesia Tahun 1945

Ketetapan Majelis Permusyawaratan Rakyat Sementara Republik Indonesia No. Xxxiii/Mprs/1967 Tentang Pencabutan Kekuasaan Pemerintahan Negara Dari Presiden Soekarno

Republik Indonesia, Undang-Undang Tentang Mahkamah Konstitusi, UU No. 23 Tahun 2004. Sebagaimana telah di perbaharui dengan Undang-Udnag No. 8 Tahun 2011

Keputusan Komisi Pemilihan Umum Republik Indonesia No. 1185/PL.01.9Kpt/06/KPU/VI/2019 Tentang Penetapan Pasangan Calon Presiden Dan Wakil Presiden Terpilih Dalam Pemilihan Umum Tahun 2019 